\title{
A Comparison of Leucine- and Acetoacetate-induced Hypo- glycemia in Man*
}

\author{
Stefan S. Fajans, John C. Floyd, Jr., Ralph F. Knopf, and \\ Jerome W. ConN \\ (From the Department of Internal Medicine, Division of Endocrinology and Metabolism and \\ the Metabolism Research Unit, the University of Michigan, Ann Arbor, Mich.)
}

In previous studies we have reported that $a$ ) marked sensitivity to leucine hypoglycemia can be induced consistently in healthy subjects after the oral administration of sulfonylureas, compounds that are known to stimulate islet cell activity (1), $b)$ a modest but significant hypoglycemic effect can be produced by administering leucine to healthy subjects without sulfonylurea pretreatment $(1,2), c)$ release of additional insulin is the primary mechanism by which leucine causes hypoglycemia in healthy subjects either with or without sensitization by sulfonylureas $(1,3)$, and $d$ ) leucine itself, rather than one of its metabolites, induces insulin release and hypoglycemia (4). The last conclusion was reached from a comparison of the effects of leucine, alpha-ketoisocaproate, and isovalerate administered in equimolar amounts to the same chlorpropamide-pretreated healthy subjects. Alpha-ketoisocaproate, the first metabolite of leucine, had a lesser effect on increasing plasma levels of insulin and on decreasing blood levels of glucose than did leucine. Isovalerate, the second metabolite in the degradation of leucine, had no hypoglycemic effect (4). Thus neither isovalerate, nor subsequent metabolites derived from its catabolism, were deemed to be likely causes for the hypoglycemia observed after administration of leucine.

Mebane and Madison (5) and Madison, Mebane, Unger, and Lochner (6) have reported that administration of ketone bodies to dogs is capable of inducing hypoglycemia and release of pancre-

\footnotetext{
* Submitted for publication April 27, 1964; accepted June 29, 1964.

Presented in part at the 46th Annual Meeting of the Endocrine Society, San Francisco, June 18-20, 1964.

Supported in part by U. S. Public Health Service grants AM 02244, AM 00888, and 2A-5001, National Institute of Arthritis and Metabolic Diseases, Bethesda, Md.
}

atic insulin. Since acetoacetate is one of the final metabolites produced in the catabolism of leucine (7), the findings of Madison and co-workers could be pertinent to the mechanism of the hypoglycemic action of leucine despite our results with infusion of isovalerate.

The studies described below were undertaken to compare the effects of equimolar amounts of intravenously administered leucine, acetoacetate, and isovalerate on blood levels of glucose, acetoacetate, leucine, and insulin in healthy subjects with and without pretreatment with sulfonylurea compounds. The results of the studies suggest that 1) although acetoacetate lowers blood glucose, leucine itself rather than acetoacetate derived from its catabolism causes insulin release and resulting hypoglycemia after its administration and 2) if acetoacetate induces insulin release in man (not demonstrated in these studies), it does so by a mechanism different from that activated by leucine.

\section{Methods}

Ten healthy young men served as subjects for this study. All subjects received three infusions before administration of chlorpropamide, ${ }^{1}$ and nine subjects received two additional infusions after administration of this sulfonylurea compound. All infusions were given during a period of 30 minutes after an overnight fast. The following infusions were given before administration of chlorpropamide: 1$) \quad l$-leucine, $0.2 \mathrm{~g}(1.52 \mathrm{mM})$ per $\mathrm{kg}$ body weight in $0.45 \%$ saline, 2) equimolar amounts of sodium acetoacetate [prepared as described by Krebs and Eggleston (8) ] in $0.45 \%$ saline, and 3) isotonic saline in equal volumes for control tests. In most subjects, the infusions were given weekly and in random sequence.

The infusions of leucine and acetoacetate were repeated in nine subjects after oral administration of chlorpropamide, $1 \mathrm{~g}$ the first day and $\frac{1}{2} \mathrm{~g}$ daily thereafter. In the majority of the experiments the period of pretreatment was 3 days. The tests were performed at weekly intervals in random sequence. For three leucine and two

1 1-Propyl-3-( $p$-chloro-benzenesulf onyl) urea. 
acetoacetate tests the period of pretreatment was from 4 to 6 days.

In addition, two of the subjects received intravenous infusions of isovalerate ( 1.52 mmoles per $\mathrm{kg}$ ) in $0.45 \%$ saline after pretreatment with chlorpropamide for 3 days. The same two subjects received intravenous infusions of a mixture of leucine and acetoacetate (1.52 mmoles per $\mathrm{kg}$, each) in $0.45 \%$ saline without pretreatment with chlorpropamide. The subjects remained asymptomatic during all tests except during infusions of isovalerate, which produced nausea.

Blood for determination of levels of glucose and plasma acetoacetate, and in some experiments for plasma leucine and insulin, was obtained 30 minutes, 15 minutes, 1 minute, and immediately before the beginning of the infusions, every 10 minutes during the first hour thereafter, and every 15 to 30 minutes for the next 2 hours.

Blood glucose levels were determined with the Technicon Auto-Analyzer with frequent verification by the Somogyi-Nelson technique (9). Plasma levels of acetoacetate were estimated by the method of Pawan (10) and those of leucine by a modification of the technique of Berry (11). Plasma levels of insulin were determined by the immunoassay of Yalow and Berson (12), as previously described in detail from this laboratory (3). At the time that the determinations were performed for the present study, the assay system showed a sensitivity of $1 \mu \mathrm{U}$ per ml plasma in the range of 0 to $20 \mu \mathrm{U}$ per ml. A single specimen run in quintuplicate gave a mean of 18.8 , with a range of 17 to $20 \mu \mathrm{U}$ per ml.

Calculations for significance were performed by 2 -factor analysis of variance and Duncan's multiple range test.

\section{Results}

Tests without pretreatment with chlorpropamide. Intravenous administration of leucine produced a significant lowering of mean blood glucose levels (Figure 1), as previously reported from this laboratory in a larger series of healthy sub-

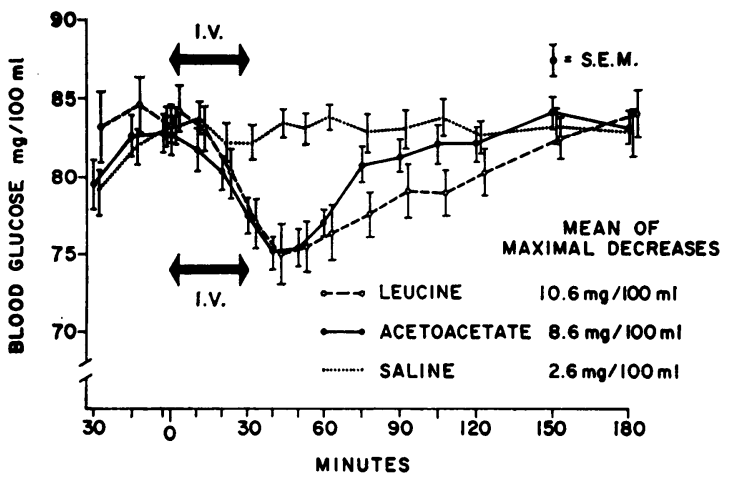

Fig. 1. EFfect of Intravenously administered leUCINE AND ACETOACETATE UPON MEAN BLOOD GLUCOSE LEVELS OF THE SAME TEN HEALTHY SUBJECTS.

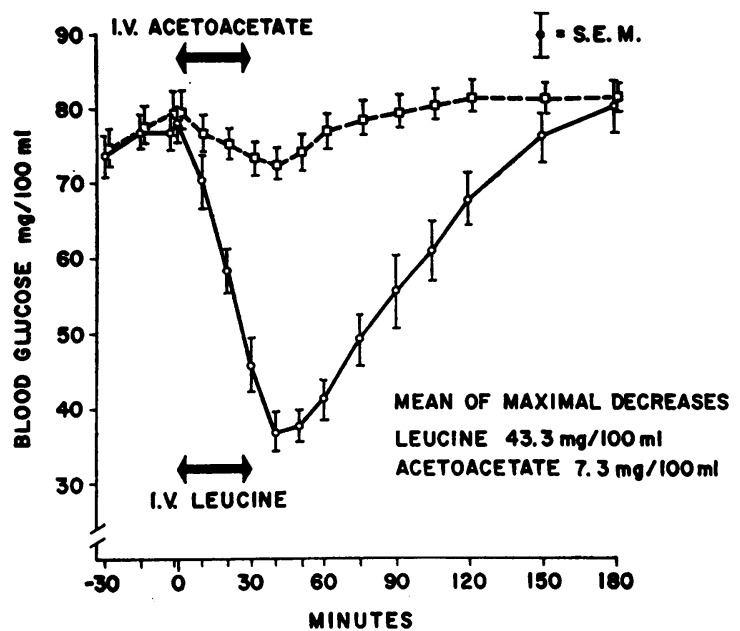

Fig. 2. EFFECtS OF INTRAVENOUSLy AdMinistered LEUCINE AND ACETOACETATE UPON MEAN BLOOD GLUCOSE LEVELS OF THE SAME NINE HEALTHY SUBJECTS PRETREATED WITH CHLORPROPAMIDE.

jects $(1,2)$. Maximal decreases in blood glucose levels in the present study ranged from 5 to 23 mg per $100 \mathrm{ml}$, with a mean of 10.6 per $100 \mathrm{ml}$.

Intravenous administration of acetoacetate likewise produced a significant lowering of blood glucose similar to that produced by leucine (Figure 1). Maximal decreases in blood glucose levels ranged from 5 to $13 \mathrm{mg}$ per $100 \mathrm{ml}$, with a mean of $8.6 \mathrm{mg}$ per $100 \mathrm{ml}$. There was no significant difference between the blood glucose changes induced by the infusions of leucine and acetoacetate, but these changes differed significantly from those observed during the control infusions of saline (Figure 1).

Infusion of the mixture of leucine and acetoacetate to two subjects produced decreases of blood glucose (4 and $11 \mathrm{mg}$ per $100 \mathrm{ml}$, respectively) that were of similar magnitude to those produced by intravenous administration of either leucine (10 and $7 \mathrm{mg}$ per $100 \mathrm{ml}$ ) or acetoacetate $(7$ and 10 $\mathrm{mg}$ per $100 \mathrm{ml}$ ) alone.

Tests after pretreatment with chlorpropamide. After administration of chlorpropamide, infusion of acetoacetate produced a similar mild hypoglycemic effect as observed before pretreatment with this sulfonylurea compound (Figure 2). The mean of the maximal decreases was $7.3 \mathrm{mg}$ per $100 \mathrm{ml}$, with a range of 3 to $11 \mathrm{mg}$ per $100 \mathrm{ml}$. This mean of the maximal decreases did not differ significantly from that obtained with infusion 
TABLE I

Levels of blood glucose and of plasma acetoacetate and leucine after intravenous administration of isovalerate to two healthy chlorpropamide-pretreated subjects

\begin{tabular}{|c|c|c|c|c|c|c|c|c|c|c|c|c|c|c|c|c|c|}
\hline \multirow[b]{2}{*}{ Subject } & \multirow{2}{*}{$\begin{array}{l}\text { Blood or } \\
\text { plasma } \\
\text { level }\end{array}$} & \multicolumn{16}{|c|}{ Time in minutes } \\
\hline & & -30 & -15 & -1 & 0 & 10 & 20 & 30 & 40 & 50 & 60 & 75 & 90 & 105 & 120 & 150 & 180 \\
\hline & & \multicolumn{16}{|c|}{$\mathrm{mg} / 100 \mathrm{ml}$} \\
\hline G.M. & $\begin{array}{l}\text { Glucose } \\
\text { Acetoacetate } \\
\text { Leucine }\end{array}$ & $\begin{array}{l}76 \\
4.1\end{array}$ & $\begin{array}{l}81 \\
3.7\end{array}$ & $\begin{array}{l}82 \\
3.7\end{array}$ & $\begin{array}{l}82 \\
2.5 \\
3.7\end{array}$ & $\begin{array}{r}80 \\
4.6 \\
3.5\end{array}$ & $\begin{array}{c}89 \\
6.6 \\
3.3\end{array}$ & $\begin{array}{l}92 \\
8.7 \\
3.7\end{array}$ & $\begin{array}{l}92 \\
9.3 \\
3.5\end{array}$ & $\begin{array}{l}91 \\
9.1 \\
3.8\end{array}$ & $\begin{array}{l}89 \\
9.5 \\
3.7\end{array}$ & $\begin{array}{c}87 \\
8.2 \\
4.1\end{array}$ & $\begin{array}{c}86 \\
6.8 \\
4.0\end{array}$ & $\begin{array}{l}86 \\
4.6 \\
4.0\end{array}$ & $\begin{array}{l}89 \\
3.7 \\
3.8\end{array}$ & $\begin{array}{l}89 \\
3.0 \\
4.1\end{array}$ & $\begin{array}{r}92 \\
5.2 \\
4.0\end{array}$ \\
\hline B.E. & $\begin{array}{l}\text { Glucose } \\
\text { Acetoacetate } \\
\text { Leucine. }\end{array}$ & $\begin{array}{l}78 \\
3.4\end{array}$ & $\begin{array}{l}82 \\
3.4\end{array}$ & $\begin{array}{l}83 \\
3.2\end{array}$ & $\begin{array}{c}84 \\
1.2 \\
3.4\end{array}$ & $\begin{array}{r}81 \\
2.9 \\
3.7\end{array}$ & $\begin{array}{r}81 \\
4.3 \\
3.4\end{array}$ & $\begin{array}{r}82 \\
5.7 \\
3.2\end{array}$ & $\begin{array}{r}82 \\
7.8 \\
3.4\end{array}$ & $\begin{array}{l}82 \\
7.1 \\
2.6\end{array}$ & $\begin{array}{c}83 \\
6.3 \\
2.9\end{array}$ & $\begin{array}{r}82 \\
5.6 \\
3.4\end{array}$ & $\begin{array}{r}8.3 \\
3.6 \\
3.0\end{array}$ & $\begin{array}{l}83 \\
3.5 \\
2.6\end{array}$ & $\begin{array}{l}85 \\
4.5 \\
2.7\end{array}$ & $\begin{array}{l}85 \\
2.2 \\
2.9\end{array}$ & $\begin{array}{r}92 \\
2.1 \\
2.6\end{array}$ \\
\hline
\end{tabular}

of acetoacetate before chlorpropamide administration. On the other hand, after administration of chlorpropamide there was a great intensification of the hypoglycemic effect observed with infusion of leucine (Figure 2), as previously reported (1). The mean of the maximal decreases was $43.3 \mathrm{mg}$ per $100 \mathrm{ml}$, with a range of 37 to $51 \mathrm{mg}$ per 100 $\mathrm{ml}$.

During or after the infusions of isovalerate, there were no decreases in blood levels of glucose (Table I). In one of the subjects there were slight increases in glucose levels.

Plasma levels of acetoacetate after administration of acetoacetate, leucine, and isovalerate. Plasma levels of acetoacetate rose promptly after the beginning of the infusions of acetoacetate (Figure 3). Since the mean plasma levels of acetoacetate at each sampling period after infusion of this metabolite were almost identical whether the subjects were pretreated with chlorpropamide or not, the results of the two series are combined in Figure 3. The mean of the maximal levels reached was $25.0 \mathrm{mg}$ per $100 \mathrm{ml}$, with a

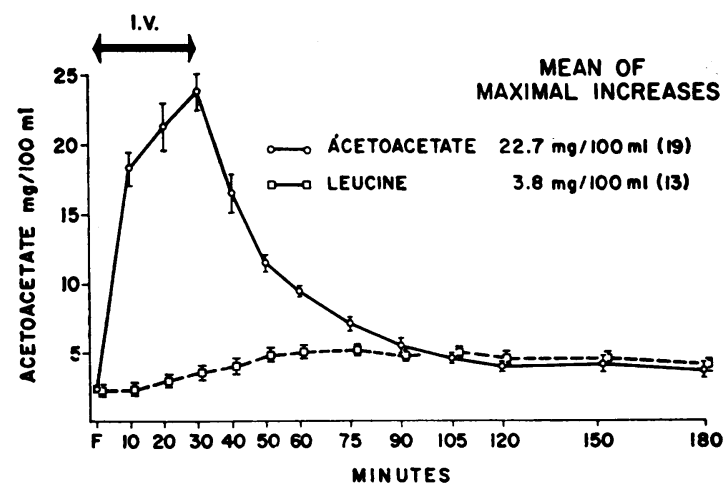

Fig. 3. Mean plasma leVels of acetoacetate after INTRAVENOUS ADMINISTRATION OF ACETOACETATE AND LEUCINE TO TEN HEALTHY SUBJECTS. range of 16.3 to $31.9 \mathrm{mg}$ per $100 \mathrm{ml}$. Maximal levels were reached 30 minutes after the beginning of the infusion in 16 of 19 experiments.

On the other hand, during and after the infusions of leucine, plasma levels of acetoacetate rose very gradually, and the maximal levels reached were much lower than those after administration of acetoacetate (Figure 3). Again there was no difference whether the subjects were pretreated with chlorpropamide or not. The mean of the maximal levels reached was $6.2 \mathrm{mg}$ per $100 \mathrm{ml}$, with a range of 4.4 to $8.3 \mathrm{mg}$ per $100 \mathrm{ml}$. Maximal increases occurred 40 to 150 (mean 84) minutes after the beginning of the infusion. The initial increases in plasma levels of acetoacetate had not occurred 10 minutes after the beginning of the leucine infusions in 9 of 13 experiments. In contrast, after prior administration of chlorpropamide, decreases in blood glucose had occurred by 10 minutes, and maximal or near-maximal decreases occurred within 40 minutes after the be-

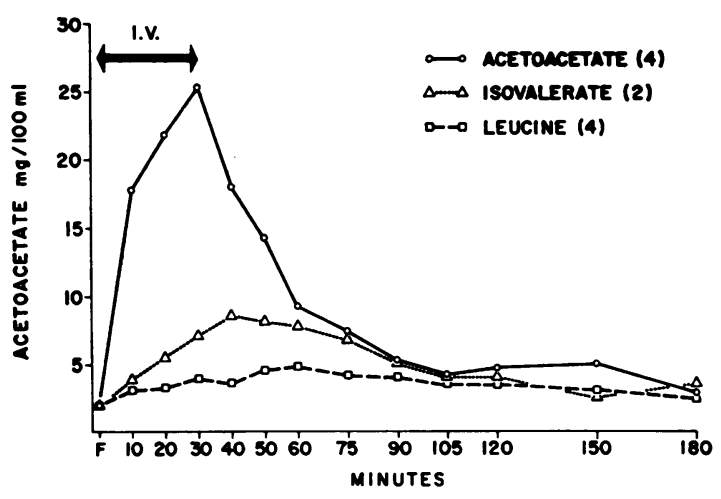

Fig. 4. Mean plasma levels of acetoacetate after INTRAVENOUS ADMINISTRATION OF LEUCINE, ISOVALERATE, AND ACETOACETAte to tWo healthy SUbJects PRETREATED WITH CHLORPROPAMIDE. 
TABLE II

Plasma levels of leucine after intravenous administration of acetoacetate to healthy subjects

\begin{tabular}{|c|c|c|c|c|c|c|c|c|c|c|c|c|}
\hline \multirow[b]{2}{*}{ Subject } & \multicolumn{12}{|c|}{ Time in minutes } \\
\hline & -1 & 0 & 10 & 20 & 30 & 40 & 50 & 60 & 75 & 90 & 105 & 120 \\
\hline & \multicolumn{12}{|c|}{$\mathrm{mg} / 100 \mathrm{ml}$} \\
\hline $\begin{array}{l}\text { T.T. } \\
\text { W.B. } \\
\text { B.E. } \\
\text { G.M. } \\
\text { B.E. } \\
\text { G.M. }\end{array}$ & $\begin{array}{l}5.1 \\
4.9 \\
3.8 \\
3.5 \\
3.4 \\
3.7\end{array}$ & $\begin{array}{l}4.7 \\
3.9 \\
3.6 \\
3.0 \\
3.4 \\
3.4\end{array}$ & $\begin{array}{l}4.6 \\
3.4 \\
3.0 \\
2.9 \\
2.7 \\
3.0\end{array}$ & $\begin{array}{l}4.3 \\
3.4 \\
2.6 \\
2.8 \\
2.5 \\
3.0\end{array}$ & $\begin{array}{l}3.9 \\
3.2 \\
2.6 \\
2.7 \\
2.7 \\
3.4\end{array}$ & $\begin{array}{l}3.1 \\
2.7 \\
3.1 \\
2.8 \\
3.7\end{array}$ & $\begin{array}{l}4.6 \\
3.1 \\
3.1 \\
3.1 \\
3.1 \\
3.8\end{array}$ & $\begin{array}{l}3.3 \\
2.6 \\
3.0 \\
2.9 \\
3.4\end{array}$ & $\begin{array}{l}3.9 \\
3.2 \\
2.7 \\
2.9 \\
3.2 \\
3.3\end{array}$ & $\begin{array}{l}4.3 \\
3.1 \\
2.6 \\
3.0 \\
3.4 \\
3.4\end{array}$ & $\begin{array}{l}4.4 \\
3.1 \\
2.6 \\
3.1 \\
3.3 \\
3.7\end{array}$ & $\begin{array}{l}3.6 \\
2.7 \\
2.9 \\
3.1 \\
3.3 \\
3.5\end{array}$ \\
\hline Mean & 4.1 & 3.7 & 3.3 & 3.1 & 3.1 & 3.1 & 3.5 & 3.0 & 3.2 & 3.3 & 3.4 & 3.2 \\
\hline
\end{tabular}

ginning of the leucine infusions in all of the experiments of this series (Figure 2).

During and after the infusions of isovalerate, increments in blood levels of acetoacetate were greater than after infusion of leucine to the same two subjects (Figure 4). Maximal increases in blood levels of acetoacetate were 6.6 and $7.0 \mathrm{mg}$ per $100 \mathrm{ml}$ after administration of isovalerate (Table I) and 3.7 and $4.2 \mathrm{mg}$ per $100 \mathrm{ml}$ after administration of leucine, respectively.

Plasma levels of leucine after administration of isovalerate and acetoacetate. As seen in Tables I and II, intravenous administration of isovalerate or acetoacetate did not cause an increase in plasma levels of leucine. The slight decreases in plasma levels of leucine after administration of acetoacetate were not statistically significant. We have previously reported on large increases in plasma levels of leucine after intravenous administration of leucine (1).

Plasma levels of insulin. Plasma levels of insulin were determined during and after intravenous administration of acetoacetate to five sub- jects without prior administration of chlorpropamide and in two subjects after pretreatment with chlorpropamide. There were no significant changes in plasma levels of insulin in any of these experiments (Table III). Previously we have reported on significant increases in plasma levels of insulin after intravenous administration of leucine (mean increases of $20 \mu \mathrm{U}$ per $\mathrm{ml}$ before and $87 \mu \mathrm{U}$ per $\mathrm{ml}$ after pretreatment with chlorpropamide) and a lack of significant changes after infusion of saline (3).

\section{Discussion}

Infusion of acetoacetate in healthy subjects produced a modest but significant lowering of blood glucose levels. This is in keeping with the results obtained by Nath and Brahmachari (13), Tidwell and Axelrod (14), and Mebane and Madison (5), who demonstrated that administration of ketone bodies may induce a lowering of blood glucose or hypoglycemia in animals. Madison and associates (6) also reported that infusion of ketone bodies to dogs results in increases in the

TABLE III

Levels of plasma insulin after intravenous administration of acetoacetate to healthy subjects

\begin{tabular}{|c|c|c|c|c|c|c|c|c|c|c|c|}
\hline \multirow[b]{2}{*}{ Pretreatment } & \multirow[b]{2}{*}{ Subject } & \multicolumn{10}{|c|}{ Time in minutes } \\
\hline & & -15 & -1 & 0 & 10 & 20 & 30 & 40 & 50 & 60 & 75 \\
\hline & & \multicolumn{10}{|c|}{$\mu U / m l$} \\
\hline None & $\begin{array}{l}\text { B.E. } \\
\text { J.C. } \\
\text { J.B. } \\
\text { J.M. } \\
\text { W.B. }\end{array}$ & $\begin{array}{r}9 \\
8 \\
18 \\
11 \\
8\end{array}$ & $\begin{array}{r}7 \\
6 \\
14 \\
14 \\
11\end{array}$ & $\begin{array}{r}9 \\
5 \\
7 \\
14 \\
7\end{array}$ & $\begin{array}{r}7 \\
10 \\
14 \\
12 \\
15\end{array}$ & $\begin{array}{l}11 \\
12\end{array}$ & $\begin{array}{r}8 \\
3 \\
13 \\
8 \\
11\end{array}$ & $\begin{array}{r}2 \\
4 \\
10 \\
16 \\
7\end{array}$ & $\begin{array}{l}3 \\
4 \\
7 \\
4\end{array}$ & $\begin{array}{l}6 \\
7 \\
9 \\
7 \\
8\end{array}$ & $\begin{array}{r}7 \\
7 \\
10 \\
8\end{array}$ \\
\hline Chlorpropamide & $\begin{array}{l}\text { B.E. } \\
\text { J.B. }\end{array}$ & $\begin{array}{r}9 \\
12\end{array}$ & $\begin{array}{r}9 \\
10\end{array}$ & $\begin{array}{r}9 \\
13\end{array}$ & $\begin{array}{l}9 \\
9\end{array}$ & $\begin{array}{r}7 \\
10\end{array}$ & $\begin{array}{r}9 \\
11\end{array}$ & $\begin{array}{r}1 \\
11\end{array}$ & $\begin{array}{l}4 \\
9\end{array}$ & $\begin{array}{l}8 \\
8\end{array}$ & $\begin{array}{l}7 \\
7\end{array}$ \\
\hline
\end{tabular}


concentration of insulin in their pancreatic venous blood. In our healthy subjects peripheral plasma levels of insulin did not increase during acetoacetate-induced hypoglycemia. Nevertheless, it is possible that the mild hypoglycemia induced by the amounts of acetoacetate infused ( 1.52 mmoles per $\mathrm{kg}$ per $\frac{1}{2}$ hour) in our healthy subjects could have been due to increased release of insulin. Small amounts of endogenously released insulin may be removed by the liver and may exert a hepatic effect without being detectable in peripheral blood $(15,16)$. The amounts of acetoacetate infused by Madison and co-workers were much larger [7.5 mmoles per kg per hour (6)] and produced more severe hypoglycemia. Furthermore, increments in plasma levels of insulin were measured by Madison and associates in pancreatic venous and not in peripheral venous blood.

Administration of leucine to healthy subjects (without prior administration of chlorpropamide) produced a lowering of blood glucose of similar magnitude to that induced by administration of isomolar amounts of acetoacetate. A significant increase in plasma levels of insulin in peripheral venous blood was previously demonstrated during leucine-induced hypoglycemia (3).

After prior administration of chlorpropamide to healthy subjects, the hypoglycemia induced by leucine was of considerably greater magnitude (fourfold) than that induced without sulfonylurea pretreatment (Figures 1 and 2). Maximal increases of plasma levels of insulin during or after administration of leucine were also four times greater after administration of chlorpropamide (3).

On the other hand, after administration of chlorpropamide to the same subjects there was no intensification of the hypoglycemic effect induced by acetoacetate, and no increases in plasma levels of insulin. Thus, if acetoacetate-induced hypoglycemia is due to increased release of insulin, these findings suggest that acetoacetate induces release of insulin by a mechanism different from that activated by leucine. They also indicate that acetoacetate derived from the infusion of leucine could not be the stimulus for the great increase in insulin release and hypoglycemia when leucine is administered to chlorpropamide-pretreated subjects.

After administration of leucine, the initial in- creases of plasma acetoacetate from control levels occurred later than 10 minutes after the beginning of the infusions in 9 of 13 experiments and were of small magnitude. On the other hand, initial decreases in blood glucose occurred within 10 minutes in all experiments after administration of chlorpropamide. Thus after administration of leucine, decreases in blood levels of glucose occurred before the small increases in blood levels of acetoacetate.

After administration of isovalerate, increases in blood levels of acetoacetate occurred more rapidly and were greater than after administration of isomolar amounts of leucine. They were not associated with any decreases in blood levels of glucose. These temporal as well as quantitative relationships indicate again that acetoacetate derived from the metabolism of leucine is not an important stimulus to insulin release and hypoglycemia after administration of leucine.

On the other hand, plasma levels of leucine rose promptly after intravenous administration of this amino acid (1). These increases preceded or were associated with increases in plasma levels of insulin and with the onset of the hypoglycemia $(1,3,4)$. All these findings in combination, together with previous evidence obtained with infusions of alpha-ketoisocaproate and isovalerate (4), would indicate that leucine itself, rather than one of its metabolites, induces insulin release and hypoglycemia after its administration.

During administration of acetoacetate plasma levels of this metabolite increased promptly to much higher levels than after infusion of leucine. These large increases preceded or were associated with the small decreases in blood glucose levels observed either with or without administration of chlorpropamide. Plasma levels of leucine did not increase after administration of acetoacetate. Thus it seems quite likely that the high plasma levels of acetoacetate obtained after its infusion are directly related to the small decreases in blood glucose observed. The mechanism by which acetoacetate induces hypoglycemia is not apparent from these experiments.

\section{Summary}

Equimolar amounts of leucine and acetoacetate were administered intravenously to 10 healthy 
subjects before and after administration of chlorpropamide. Leucine and acetoacetate induced similar mild hypoglycemia before administration of chlorpropamide. After administration of chlorpropamide to the same subjects, acetoacetate produced the same degree of hypoglycemia while leucine now produced intense hypoglycemia. Peripheral plasma levels of insulin did not rise after administration of acetoacetate. Increases in plasma levels of acetoacetate after infusions of leucine were of small magnitude and occurred only after a decrease in blood levels of glucose had occurred. In additional experiments two subjects received infusions of isovalerate after pretreatment with chlorpropamide. In these studies (isovalerate), during which there were no decreases in blood glucose, increases in plasma levels of acetoacetate occurred more rapidly and were greater than after administration of leucine. Plasma levels of acetoacetate rose sharply after administration of acetoacetate.

These findings suggest that 1) although acetoacetate lowers blood glucose, leucine itself rather than acetoacetate derived from its catabolism causes insulin release and hypoglycemia after its administration and 2) if acetoacetate induces insulin release in man, it does so by a mechanism different from that activated by leucine.

\section{References}

1. Fajans, S. S., R. F. Knopf, J. C. Floyd, Jr., L. Power, and J. W. Conn. The experimental induction in man of sensitivity to leucine hypoglycemia. J. clin. Invest. 1963, 42, 216.

2. Fajans, S. S., R. F. Knopf, J. C. Floyd, Jr., and J. W. Conn. On the physiologic significance of leucine hypoglycemia in healthy subjects (abstract). J. Lab. clin. Med. 1962, 60, 873.

3. Floyd, J. C., Jr., S. S. Fajans, R. F. Knopf, and J. W. Conn. Evidence that insulin release is the mechanism for experimentally induced leucine hypoglycemia in man. J. clin. Invest. 1963, 42, 1714.

4. Knopf, R. F., S. S. Fajans, J. C. Floyd, Jr., and J. W. Conn. Comparison of experimentally in- duced and naturally occurring sensitivity to leucine hypoglycemia. J. clin. Endocr. 1963, 23, 579.

5. Mebane, D., and L. L. Madison. Hypoglycemic action of ketones. I. Effects of ketones on hepatic glucose output and peripheral glucose utilization. J. Lab. clin. Med. 1964, 63, 177.

6. Madison, L. L., D. Mebane, R. H. Unger, and A. Lochner. The hypoglycemic action of ketones. II. Evidence for a stimulatory feedback of ketones on the pancreatic beta cells. J. clin. Invest. 1964, 43, 408.

7. Coon, M. J., W. G. Robinson, and B. K. Bachhawat. Enzymatic studies on the biological degradation of the branched chain amino acids in A Symposium on Amino Acid Metabolism, W. D. McElroy and H. B. Glass, Eds. Baltimore, Johns Hopkins Press, 1955 , p. 431.

8. Krebs, H. A., and L. V. Eggleston. Metabolism of acetoacetate in animal tissues. I. Biochem J. 1945, 39, 408 .

9. Nelson, N. A photometric adaptation of the Somogyi method for the determination of glucose. J. biol. Chem. 1944, 153, 375.

10. Pawan, G. L. S. A simple micromethod for the quantitative determination of acetone and acetoacetate in biological fluids. Biochem. J. 1958, 68, $33 \mathrm{P}$.

11. Berry, H. K. Paper chromatographic method for estimation of phenylalanine. Proc. Soc. exp. Biol. (N. Y.) 1957, 95, 71.

12. Yalow, R. S., and S. A. Berson. Immunoassay of endogenous plasma insulin in man. $\mathrm{J}$. clin. Invest. 1960, 39, 1157.

13. Nath, M. C., and H. D. Brahmachari. Studies on the ætiological factors responsible for the onset of diabetic symptoms. Part I. Effect of prolonged injection of intermediary fat metabolites on the blood-sugar level in the normal animals. Indian J. med. Res. 1949, 37, 61.

14. Tidwell, H. C., and H. E. Axelrod. Blood sugar after injection of acetoacetate. J. biol. Chem. 1948, 172, 179.

15. Madison, L. L., B. Combes, R. H. Unger, and N. Kaplan. The relationship between the mechanism of action of the sulfonylureas and the secretion of insulin into the portal circulation. Ann. N. Y. Acad. Sci. 1959, 74, 548.

16. Samols, E., and J. A. Ryder. Studies on tissue uptake of insulin in man using a differential immunoassay for endogenous and exogenous insulin. $\mathrm{J}$. clin. Invest. 1961, 40, 2092. 